\title{
Genetic Characterization and Dollar Spot Fungus Susceptibility in Accessions of Festuca rubra from Northern Spain
}

\author{
Jose A. Oliveira \\ Departamento de Biología de Organismos y Sistemas, Área de Producción \\ Vegetal, Escuela Politécnica de Mieres, Universidad de Oviedo, 33600 \\ Mieres, Asturias, Spain
}

Ana B. Monteagudo

CIAM (Centro de Investigaciones Agrarias de Mabegondo)-INGACAL (Instituto Galego de Calidade Alimentaria), Apdo. 10, 15080 A Coruña, Galicia, Spain

\author{
Suleiman S. Bughrara ${ }^{1}$ \\ Department of Crop and Soil Sciences, Michigan State University, 286 PSSB, \\ East Lansing, MI 48824-1325
}

\section{Jose L. Martínez and Ana Salas}

Servicios Cientificos-Técnicos, Biomedicina. Edificio CientificoTecnológico, Planta Baja, Campus de El Cristo, Universidad de Oviedo, 33006 Oviedo, Asturias, Spain

\section{Esther Novo-Uzal and Federico Pomar}

Departamento de Biología Animal, Biología Vegetal y Ecología, Área de Fisiología Vegetal, Facultad de Ciencias-Universidad da Coruña, 15008 A Coruña, Galicia, Spain

Additional index words. amplified fragment length polymorphism, artificial infection, cluster analysis, flow cytometry, principal coordinate analysis, red fescue

\begin{abstract}
The objective of the present study was to characterize the diversity of 15 Festuca rubra accessions collected from northern Spain on the basis of amplified fragment length polymorphism (AFLP) and flow cytometry variation. Additionally, all accessions along with the cultivar Wilma (Festuca nigrescens ssp. nigrescens) were evaluated for susceptibility to one isolate of dollar spot fungus (Sclerotinia homoeocarpa F.T. Bennett) collected in Asturias. Five AFLP primer combinations of EcoRI and $M s e I$ produced 980 bands; $82.3 \%$ were polymorphic and used for analysis. The best combination of primers was EcoRIAGC+MseI-CAG, because these displayed the highest degree of polymorphism. Jaccard's similarity coefficients between accessions varied from 0.30 to 0.63 and revealed low genetic similarity. Both the unweighted pair group method with arithmetic mean dendrogram and principal coordinate analysis distinguished two groups of accessions. Genetic variability in these accessions was not related to the geographic origin or to the agronomic data. Three accessions exhibited moderate resistance to dollar spot disease and may be valuable parent material for introducing this resistance in other susceptible cultivars.
\end{abstract}

There are more than 100 taxa of the genus Festuca in the Iberian Peninsula, which is one of its main centers of diversification (De Nova et al., 2006).

Received for publication 22 Sept. 2009. Accepted for publication 2 Feb. 2010.

The authors acknowledge financial support from the INIA (Instituto Nacional de Investigación y Tecnología Agraria y Alimentaria de España), project RF-025-C2-1 (2003-2005).

We are indebted to Ms. Leticia Labra Villar for assistance with the AFLP laboratory work.

${ }^{1}$ To whom reprint requests should be addressed; e-mail bughrara@msu.edu.
The fescues are divided into two types on the basis of leaf texture: the coarse fescues, e.g., Festuca arundinacea and Festuca pratensis, and the fine fescues, e.g., the Festuca rubra and Festuca ovina groups (Turgeon, 2005).

Species of $F$. rubra provide the best turfgrass for dry, moderately shaded areas and infertile, acidic soil. They exhibit poor traffic tolerance and their use in areas with heavy traffic or athletic fields should be avoided (Turgeon, 2005).

Laser flow cytometry has become a valuable tool for measuring the nuclear DNA content of plants. The information obtained can be used to determine ploidy levels (Arumuganathan and Earle, 1991). Amplified fragment length polymorphism (AFLP) markers have been used successfully to determine the genetic diversity of forage and turfgrasses (Zhao et al., 2006). Mian et al. (2002) used AFLP markers to determine genetic diversity and to distinguish 18 populations of tall fescue in the United States by the DNA bulk strategy. Majidi et al. (2006) used the same technique to analyze genetic variation and relationships in 34 Iranian fescue accessions. The fungus Sclerotinia homoeocarpa F.T. Bennett causes dollar spot, a leaf disease of closely mowed turf throughout the world (Bonos et al., 2003). Symptoms appear as bleached spots approximately the size of a silver dollar that may overlap to produce large irregular areas of sunken dead turfgrass (Walsh et al., 1999). The development of red fescue cultivars that are resistant to dollar spot would therefore reduce the cost and environmental impact of fungicide applications. Breeding programs for dollar spot resistance in the United States are mainly based on materials collected from old golf courses (Bonos et al., 2003). Other possible sources of dollar spot resistance originate from PIs or accessions. The objective of the present study was to characterize the diversity of Festuca rubra accessions collected from northern Spain on the basis of AFLP and flow cytometry variation and dollar spot susceptibility by growth chamber inoculations with one isolate of Sclerotina homoeocarpa collected in Asturias. Knowledge of such variability should prove useful in assessing the potential value of these accessions in breeding programs for turf and forage plants.

\section{Materials and Methods}

Plant materials. Seeds from 15 accessions of $F$. rubra were collected from grasslands in northern Spain in 2000 (Table 1). For each accession, seeds were collected from at least 50 plants in an ecologically homogeneous area of 100 to $1000 \mathrm{~m}^{2}$. All the seeds were stored in waterproof packages, at 0 to $4^{\circ} \mathrm{C}$, in the CIAM seed bank [Centro de Investigaciones Agrarias de Mabegondo (FAO Code $=$ ESP119), Galicia, NW Spain]. The 15 accessions of $F$. rubra were morphologically characterized and grouped into four Festuca taxa: seven (P01, P02, P05, P06, P07, P09, $\mathrm{P} 11)$ were identified as $F$. heteromalla (rhizomes present); two (P03 and $\mathrm{P} 04$ ) as F. trichophylla ssp. asperifolia (rhizomes present); two (P08 and P10 as F. nigrescens ssp. microphylla (absence of rhizomes); and four (P12, P13, P14, and P16) as F. rubra ssp. pruinosa (rhizomes present). The chromosome number of all the accessions is $2 n=6 x=42$ (Oliveira et al., 2008).

The correspondence between the inventory numbers used in the CIAM seed bank and the codes used by Oliveira et al. (2008) are as follows: $1305-\mathrm{P} 05=2 ; 1302-\mathrm{P} 02=3$; $1301-\mathrm{P} 01=4 ; 1303-\mathrm{P} 03=7 ; 1304-\mathrm{P} 04=8$; $1306-\mathrm{P} 06=11 ; 1307-\mathrm{P} 07=13 ; 1311-\mathrm{P} 11=14$; $1309-\mathrm{P} 09=15 ; 1310-\mathrm{P} 10=16 ; 1314-\mathrm{P} 14=19$; 
1313-P13 = 20; 1308-P08 = 21; 1312-P12 = 27; and $1316-\mathrm{P} 16=29$.

DNA extraction and amplified fragment length polymorphism analysis. In Nov. 2007, 30 seeds of each of 15 accessions were sown in pots and the plantlets grown in a greenhouse (Universidad de Oviedo, Mieres, Asturias, Spain). Young leaves were collected from the plants, and the total genomic DNA was extracted from 20 plants per accession with a commercial kit for plant samples (E.Z.N.A. ®) Plant DNA Mini Kit D3486/ D3485-01, 50 prep.) following the manufacturer's instructions. The DNA was conserved at $-20{ }^{\circ} \mathrm{C}$ until use. An ultraviolet/visible spectrophotometer was used (wavelength $260 \mathrm{~nm}$ ) to quantify the amount of DNA extracted per sample. Equal amounts of DNA extracted from each of five plants per accession were mixed to produce bulk DNA. In total, four bulk DNA samples per accession were obtained.

AFLP analysis was performed in accordance with the methods described by Vos et al. (1995). Genomic DNA (350 ng per sample) was digested with EcoRI and MseI restriction enzymes at $37^{\circ} \mathrm{C}$ for $3 \mathrm{~h}$. The restricted DNA fragments were ligated to EcoRI and MseI adaptors and incubated for $2 \mathrm{~h}$ at $25^{\circ} \mathrm{C}$ and the product was diluted (1:10). Preamplification reactions were performed with $E c o \mathrm{RI}+\mathrm{A}$ and $M s e \mathrm{I}+\mathrm{C}$ AFLP primers. The preamplification mix was diluted (1:50) and $5 \mu \mathrm{L}$ was added to the selective amplification medium containing $1 \times$ reaction buffer, $30 \mathrm{ng}$ each of primers $E c o$ RI +3 and $M s e I+3,0.25 \mathrm{mmol}$ of dNTP/L, and $1 \mathrm{U}$ of Taq DNA polymerase in a final volume of $20 \mu \mathrm{L}$. Five combinations of primer +3 were used with either the $E c o \mathrm{RI}+3$ primer end-labeled with 6-FAM (blue), NED (yellow), or HEX (green) fluorochromes with the unlabeled $\mathrm{Mse}+3$ primer $(\mathrm{E}-\mathrm{ACC}+\mathrm{M}-$ CAA; E-AGG+M-CAA; E-ACG+M-CAA) and two $\mathrm{Mse}+3$ primers end-labeled with 6FAM or NED with the unlabeled EcoRI+3 primer (E-AGC+M-CAG; E-AGC+M-CTG) (Table 2). The polymerase chain reaction products were separated by capillary electrophoresis and analyzed in an ABI PRISM ${ }^{\circledR}$ 3100 Genetic Analyzer (Applied Biosystems). Automated data analysis with GeneMapper® software was used for scoring AFLP samples. The reproducibility of the AFLP results was tested by replicating the complete procedure in five DNA samples for all the primer combinations, and amplification results were then compared for accuracy.

Flow cytometry. Following the technique reported by Dolezel et al. (1994), 100 to 200 $\mathrm{mg}$ of fresh leaves was collected and chopped into pieces ( 1 to $2 \mathrm{~mm}$ ) in a petri dish with $2 \mathrm{~mL}$ of Otto I buffer $(0.1 \mathrm{M}$ citric acid, $0.5 \%$ $\mathrm{v} / \mathrm{v}$ Tween 20 stored at $4{ }^{\circ} \mathrm{C}$ ) to lyse the cells and obtain the nuclei. The petri dish was maintained on ice for $15 \mathrm{~min}$. The suspension was filtered through a 50- $\mu$ m nylon mesh in a tube, and $350 \mu \mathrm{L}$ of Otto II buffer $(0.4 \mathrm{M}$ sodium dihydrogen phosphate stored at room temperature), then $50 \mu \mathrm{L}$ of $100 \mu \mathrm{g} / \mathrm{mL}$ RNase $\mathrm{A}$ and $50 \mu \mathrm{L}$ of a $140 \mu \mathrm{g} / \mathrm{mL}$ solution of propidium iodide added. As an internal control, $5 \mu \mathrm{L}$ of an optimized solution of chicken red blood cells was also added. The samples were incubated for $10 \mathrm{~min}$ on ice and then analyzed in a flow cytometer (Cytomics FC500; Beckman Coulter). At least 10,000 events per sample were acquired. The fluorescent signals were detected with an FL3 detector and the corresponding data analyzed by use of RXP Cytomics software. For each

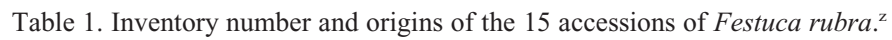

\begin{tabular}{|c|c|c|c|c|}
\hline Inventory number & Origin & Lat & Long & Alt \\
\hline P01 & Villanueva de Oscos & $43.18 \mathrm{~N}$ & $06.59 \mathrm{~W}$ & 650 \\
\hline $\mathrm{P} 02$ & Armada & $43.07 \mathrm{~N}$ & $05.51 \mathrm{~W}$ & 1100 \\
\hline $\mathrm{P} 03$ & Puerto de Tarna & $43.07 \mathrm{~N}$ & $05.14 \mathrm{~W}$ & 1490 \\
\hline P04 & Tanes & $43.15 \mathrm{~N}$ & $05.25 \mathrm{~W}$ & 495 \\
\hline P05 & Folgueiras & $43.25 \mathrm{~N}$ & $07.10 \mathrm{~W}$ & 300 \\
\hline P06 & Alto de Cobertoria & $43.10 \mathrm{~N}$ & $05.58 \mathrm{~W}$ & 1179 \\
\hline P07 & Paramios & $43.22 \mathrm{~N}$ & $07.01 \mathrm{~W}$ & 500 \\
\hline P08 & La Uña & $43.03 \mathrm{~N}$ & $05.07 \mathrm{~W}$ & 1250 \\
\hline P09 & Acebedo & $43.03 \mathrm{~N}$ & $05.07 \mathrm{~W}$ & 1180 \\
\hline P10 & Sta. Eulalia de Oscos & $43.15 \mathrm{~N}$ & $07.01 \mathrm{~W}$ & 560 \\
\hline P11 & Carande & $42.50 \mathrm{~N}$ & $04.50 \mathrm{~W}$ & 1000 \\
\hline P12 & Playa de Pormenande & $43.32 \mathrm{~N}$ & $06.49 \mathrm{~W}$ & 3 \\
\hline P13 & Playa de Navia & $43.33 \mathrm{~N}$ & $06.43 \mathrm{~W}$ & 6 \\
\hline P14 & Playa de Penarronda & $43.32 \mathrm{~N}$ & $06.59 \mathrm{~W}$ & 3 \\
\hline $\mathrm{P} 16$ & Faro de Ribadeo & $43.33 \mathrm{~N}$ & $07.02 \mathrm{~W}$ & 9 \\
\hline
\end{tabular}

${ }^{\mathrm{z}}$ Latitude (Lat) and longitude (Long) in decimal degrees and altitude (Alt) in meters above sea level.

Table 2. Primer combinations and bands scored in amplified fragment length polymorphism profiling.

\begin{tabular}{lccccc}
\hline No. & Primer combinations & $\begin{array}{c}\text { Total } \\
\text { bands }\end{array}$ & $\begin{array}{c}\text { Polymorphic } \\
\text { bands }\end{array}$ & $\begin{array}{c}\text { Polymorphic } \\
\text { bands (\%) }\end{array}$ & $\begin{array}{c}\text { Unique } \\
\text { bands }\end{array}$ \\
\hline 1 & E-ACC+M-CAA & 205 & 154 & 75.1 & 2 \\
2 & E-AGG+M-CAA & 179 & 142 & 79.3 & 4 \\
3 & E-ACG+M-CAA & 174 & 145 & 83.3 & 3 \\
4 & E-AGC+M-CAG & 240 & 201 & 83.7 & 9 \\
5 & E-AGC+M-CTG & 182 & 165 & 90.7 & 5 \\
Total & & 980 & 807 & 82.3 & 23 \\
Mean & & 196 & 161 & 82.3 & 4.6 \\
\hline
\end{tabular}

sample, the plant nuclear 2C DNA content (measured in pg) was determined from the ratio of the mean peak value for the plant sample and the peak value for the chicken red blood cells multiplied by the known nuclear DNA content of chicken red blood cells, i.e., 2.33 pg (Costich et al., 1991). Three replicated flow cytometry measurements of 2C DNA content were taken for each of the 15 accessions and the commercial cultivar Wilma.

Dollar spot characterization. Symptomatic perennial ryegrass leaf blades were collected from the 'Las Caldas' golf course in Oviedo (Asturias). Fresh leaves were cut from diseased plants showing symptoms of dollar spot and immediately placed on ice (inside a plastic bag). Each leaf was cut into pieces $\approx 5 \mathrm{~cm}$ long and placed in a small beaker with $1 \%(\mathrm{v} / \mathrm{v})$ sodium hypochlorite for $30 \mathrm{~s}$ to sterilize the surface, then rinsed twice in sterile water, placed on potato dextrose agar (PDA), and incubated at $25^{\circ} \mathrm{C}$ for $5 \mathrm{~d}$ (Bonos et al., 2003). Grown on PDA, $S$. homoeocarpa produces fluffy white mycelia with extensive aerial mycelia, covering a standard petri dish in $5 \mathrm{~d}$ (Fig. 1).

The SH01CIAM S. homoeocarpa isolate was grown on sterilized kentucky bluegrass seed for inoculation. Two hundred grams of kentucky bluegrass seed were autoclaved for $15 \mathrm{~min}$ at $151^{\circ} \mathrm{C}$. Seventy-five milliliters of $\mathrm{dH}_{2} \mathrm{O}$ was added to the kentucky bluegrass seed in an Erlenmeyer flask and left overnight. Single isolates of $S$. homoeocarpa growing on PDA were cut into $1 \times 1-\mathrm{cm}$ pieces and transferred to the flask. Isolates were grown separately in 1-L flasks for $\approx 3$ weeks at room temperature and then dried on newspaper for $3 \mathrm{~d}$. The dried inoculum was subsequently used to inoculate the plants for evaluation of dollar spot sensitivity.

Sixty seeds of each accession and the control 'Wilma' were germinated in 60-cell trays $(30 \times 50 \times 4.7 \mathrm{~cm}), 61 \mathrm{~mL}$ volume per cell (Projar, Quart de Poblet, Valencia, Spain), containing a soilless mix of peatmoss and vermiculite $(3: 1, \mathrm{v} / \mathrm{v})$ in the greenhouse in Sept. 2008. Seedlings were maintained in the greenhouse with average temperatures of $16^{\circ} \mathrm{C}$

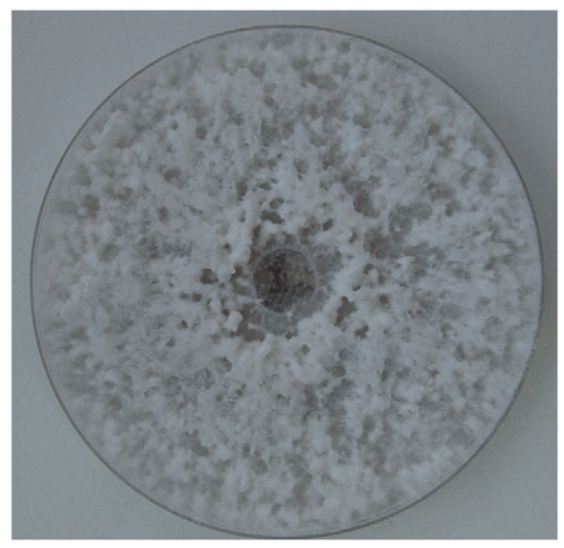

Fig. 1. SH01CIAM Sclerotinia homoeocarpa isolate obtained in the red fescue diseased plants on a potato dextrose agar petri dish and incubated at $25^{\circ} \mathrm{C}$ during $5 \mathrm{~d}$ (view from above). 
(11 to $20^{\circ} \mathrm{C}$ ), average relative humidity of $92 \%(83 \%$ to $99 \%)$, and average photoperiod of 11:13 (light:dark). Seedlings were watered with once daily with tap water and fertilized every 2 weeks with Scott's Peters Professional ${ }^{\circledR}$ 20-20-20 General Purpose to provide $100 \mathrm{ppm}$ nitrogen $(2,4 \mathrm{~kg} \mathrm{~N} / \mathrm{ha})$ The plants were cut to $5 \mathrm{~cm}$ once before the transplant in Dec. 2008.

Individual seedlings were transferred to TEKU-Tainer square pots $9.5 \mathrm{~cm}$ high and $9 \mathrm{~cm}$ inside (Pöppelmann Ibérica S.R.L., Barcelona, Spain) containing the same soilless mix than for seed germination and grown for 8 more weeks inside BSP-9 watering trays of $54 \times 39 \times 9 \mathrm{~cm}$ (Dalpen, Gijon, Asturias, Spain). After maintaining plants for 8 weeks in the greenhouse, the watering trays were moved into a growth chamber (Universidad de Oviedo, Mieres, Asturias, Spain) for a 3-d acclimation period before inoculation of the pathogen. Evaluation of dollar spot susceptibility was carried out in a growth chamber adjusted to provide a 12 -h photoperiod $(13,000$ $\mathrm{lx}$ ) and temperature ranging from 22 to $27^{\circ} \mathrm{C}$, which is optimal for maximum pathogenicity (Walsh et al., 1999) in Feb. 2009. In the growth chamber, the experiment was arranged within a randomized complete block design with the treatment accession with 15 accessions and one control arranged in a random order in each of the two replications of 15 random plants per accession and replication (in total 30 random plants per accession).

Equal amounts of inoculum ( $1 \mathrm{~g})$ of the SH01CIAM isolate were placed in the center of each pot. The watering trays were filled with water and placed inside plastic bags to maintain high humidity (near saturated environment) and optimize the severity of the disease. The plants were visually inspected 3 weeks after the inoculation and their resistance/susceptibility to the disease was scored on a scale of 1 to 9 , in which 1 = plant completely brown from disease and $9=$ no symptoms (Chakraborty et al., 2006). To assess the nature of the pathogen infecting the red fescue accessions, polymerase chain reaction was performed on the diseased plants (Fig. 2) and produced a 500-bp band, which corresponds to the amplicon size obtained from the initial reference sample of $S$. homoeocarpa obtained in the golf course. Furthermore, the sample of asymptomatic red fescue plants did not amplify. Moreover, the amplified regions were sequenced, obtaining the same nucleotidic sequence in the initial reference sample obtained from the golf course, in the diseased plant after inoculation and in a reference $S$. homoeocarpa sample received from the CBS Fungal Biodiversity Center (Utrecht, The Netherlands; CBS 510.89).

Data analysis. AFLP bands that showed clear polymorphisms were scored as present (" 1 ") or absent ("0"). AFLP fragments were scored as present for a given accession if they were detected in any individuals of these accessions. Bands of different electrophoretic mobilities were assumed to be nonallelic, whereas bands of the same mobility were assumed to be allelic. Some ambiguous bands were ignored. Genetic diversity analyses were conducted by use of Numerical Taxonomy and the Multivariate Analysis System, NTSYSpc Version 2.1 (Rohlf, 2003). Genetic similarities based on Jaccard's coefficients (GSj) were calculated among all possible pairs with the SIMQUAL option and ordered in a similarity matrix. The similarity matrix was run by sequential, agglomerative, hierarchical, nested clustering (SAHN) by the unweighted pair group method with arithmetic mean (UPGMA) as an option. The dendrogram and cluster groupings were constructed by the UPGMA clustering algorithm from the SAHN option of NTSYSpc Version 2.1. Bootstrap analysis $(P$ Bootstrap value), with 1000 resamples, was computed by use of Win boot (Yap and Nelson, 1996) to determine the confidence limits of the UPGMA dendrogram nodes. The cophenetic correlation coefficient $(r)$ was calculated to measure goodness of fit between the similarity and cophenetic (the resultant phenetic tree) matrices. The significance of the cophenetic coefficient was determined by 1000 random permutations. Principle coordinate analysis based on genetic similarity matrices was performed with the DCENTER and EIGEN options of the NTSYS-pc Version 2.1 to identify the number of groups based on eigenvectors. The principal coordinate analysis

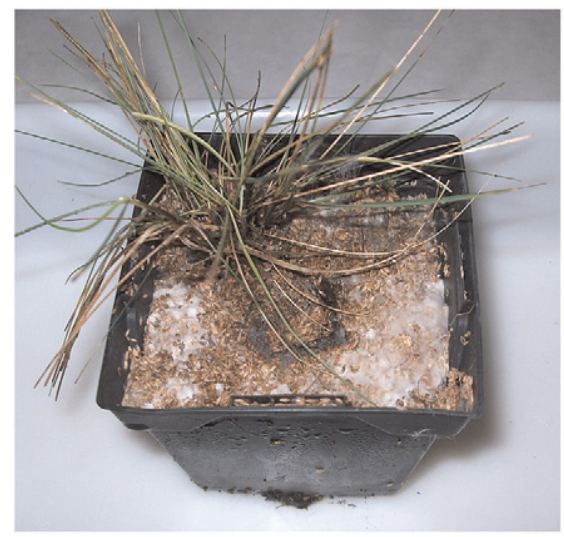

Fig. 2. Symptoms of dollar spot disease on F. rubra 3 weeks after inoculation. result was displayed by the Mod3D plot module. Correlation between the matrices obtained with the AFLP markers and the agronomic and geographical (longitude and latitude in UTM units and altitude in meters above the sea level) matrices obtained by Oliveira et al. (2008) were estimated by means of the Mantel Matrix Correspondence Test of 1000 random permutations (Mantel, 1967) from NTSYS-pc Version 2.1. For evaluation of disease, analysis of variance was applied to the data obtained in the third week after inoculation considering the effects of replication and accession. Normality of the residuals was tested by the Shapiro-Wilk (W) test and the homogeneity of residual variances was tested by Levene's test. Separation of accessions was performed by the least significant difference test. Analysis of variance was performed for DNA content among accessions. Statistical analyses were computed with the statistical package SPSS Version 15 (SPSS $\left.{ }^{2}, 2006\right)$.

\section{Results}

Amplified fragment length polymorphism markers. Five primer combinations produced 980 bands of AFLP markers ranging in size from 50 to $500 \mathrm{bp}$. Of the 980 bands scored, $807(82.3 \%)$ were polymorphic (Table 2$)$. The number of polymorphic bands (or probes) for each primer combination varied from 142 to 201 . The E-AGC+M-CAG primer combination generated the largest number of polymorphic fragments (201), whereas the E-AGG+M-CAA primer combination produced the smallest number of polymorphic fragments (142 bands). Pairwise comparison of genetic similarity among accessions revealed intermediate genetic diversity within the northern Spain red fescues. The genetic similarity (Jaccard) coefficients $(\mathrm{GSj})$ ranged from 0.30 to 0.63 (mean 0.55) (Table 3). The most similar accessions were $\mathrm{P} 11$ to $\mathrm{P} 13(\mathrm{GSj}=$ $0.63), \mathrm{P} 11$ to $\mathrm{P} 09(\mathrm{GSj}=0.62)$, and $\mathrm{P} 14$ to $\mathrm{P} 16$ (0.62). On the other hand, the least similar accessions $(\mathrm{GSj}=0.30)$ were $\mathrm{P} 02$ and $\mathrm{P} 12$. The UPGMA cluster tree generated by Jaccard's similarity coefficient matrix is shown in Figure 3. At $\mathrm{GSj}=0.42$, all the

Table 3. Jaccard similarity coefficients for 15 red fescue accessions (F. heteromalla: P01, P02, P05, P06, $\mathrm{P} 07, \mathrm{P} 09, \mathrm{P} 11 ;$ F. trichophylla ssp. asperifolia: $\mathrm{P} 03, \mathrm{P} 04 ; F$. nigrescens ssp. microphylla: $\mathrm{P} 08$ and $\mathrm{P} 10$ and $F$. rubra ssp. pruinosa: P12, P13, P14, and P16) based on amplified fragment length polymorphism profiling.

\begin{tabular}{llllllllllllllll}
\hline & P01 & P02 & P03 & P04 & P05 & P06 & P07 & P08 & P09 & P10 & P11 & P12 & P13 & P14 & P16 \\
\hline P01 & 1.00 & & & & & & & & & & & & & \\
P02 & 0.33 & 1.00 & & & & & & & & & & & & \\
P03 & 0.36 & 0.44 & 1.00 & & & & & & & & & & & \\
P04 & 0.52 & 0.42 & 0.46 & 1.00 & & & & & & & & & & \\
P05 & 0.40 & 0.52 & 0.49 & 0.46 & 100 & & & & & & & & & \\
P06 & 0.43 & 0.51 & 0.54 & 0.55 & 0.54 & 1.00 & & & & & & & & \\
P07 & 0.56 & 0.37 & 0.43 & 0.61 & 0.45 & 0.49 & 100 & & & & & & & \\
P08 & 0.41 & 0.32 & 0.44 & 0.50 & 0.38 & 0.43 & 0.49 & 1.00 & & & & & & \\
P09 & 0.47 & 0.36 & 0.46 & 0.56 & 0.41 & 0.48 & 0.53 & 0.58 & 1.00 & & & & & \\
P10 & 0.54 & 0.37 & 0.46 & 0.58 & 0.45 & 0.49 & 0.57 & 0.52 & 0.54 & 1.00 & & & & \\
P11 & 0.51 & 0.37 & 0.45 & 0.59 & 0.43 & 0.51 & 0.56 & 0.51 & 0.62 & 0.61 & 1.00 & & & & \\
P12 & 0.43 & 0.30 & 0.48 & 0.48 & 0.41 & 0.44 & 0.48 & 0.52 & 0.56 & 0.53 & 0.52 & 1.00 & & & \\
P13 & 0.50 & 0.35 & 0.45 & 0.58 & 0.43 & 0.49 & 0.55 & 0.56 & 0.60 & 0.58 & 0.63 & 0.58 & 1.00 & & \\
P14 & 0.43 & 0.32 & 0.47 & 0.53 & 0.39 & 0.45 & 0.53 & 0.54 & 0.55 & 0.54 & 0.56 & 0.58 & 0.58 & 1.00 & \\
P16 & 0.44 & 0.35 & 0.49 & 0.51 & 0.42 & 0.47 & 0.50 & 0.51 & 0.54 & 0.55 & 0.58 & 0.57 & 0.59 & 0.62 & 1.00 \\
\hline
\end{tabular}


accessions were included in the group showing low similarity among the accessions. At $\mathrm{GSj}=0.48$, the accessions were included in two major clusters, each of which did not correspond to separate species. This clearly shows greater intraspecific than interspecific variation at the genomic level, although accessions of one species may have originated from distinct geographical areas. The first group consisted of accession numbers $\mathrm{P} 01$, P04, P07, P10, P09, P11, P13, P12, P14, P16, and $\mathrm{P} 08$ with an average $\mathrm{GSj}=0.54$ (0.41 to $0.63)$. The second group consisted of accessions $\mathrm{P} 02, \mathrm{P} 03, \mathrm{P} 05$, and $\mathrm{P} 06$ with $\mathrm{GSj}=0.51$ ( 0.44 to 0.54$)$. To test the dendrogram goodness of fit, the cophenetic correlation between the similarity matrix and the corresponding cophenetic matrix was calculated. The cophenetic correlation coefficient value, $r=0.83$ (approximate Mantel $t$ test: $\mathrm{t}=5.1436$; probability random $\mathrm{Z}<$ observations $\mathrm{Z}: P=$ $1.0000)$ suggested a good fit between the dendrogram cluster and the similarity matrix from which it was derived based on the findings of Sneath and Sokal (1973). However, they were not indicative of grouping because the bootstrap values of some clusters were lower than 50\% (Jianming et al., 2006), although some accessions were closely related. The results of the principal coordinate analysis are shown in Figure 4. Principal coordinate 1 (Dim-1) accounted for $15.88 \%$ and mainly separated the subspecies from the remaining subspecies. Principal coordinates 2 and 3 (accounting for $10.83 \%$ and $7.91 \%$, respectively) provided further differentiation. Principal coordinate analysis with the same data set was generally consistent with results from the cluster analysis. Comparison between an agronomic matrix (Euclidean dissimilarity coefficients) obtained from Oliveira et al. (2008) and the AFLP data showed a looser correspondence. The Mantel $\mathrm{Z}$ statistic indicated a nonsignificant correlation $(r=-0.04, P=0.4011)$ between both matrices, suggesting that the two procedures give different estimates of genetic relations among the red fescue accessions. However, some consistencies were found; for example, P11 and P13 are clustered together on the basis of both agronomic and molecular data sets. The negative sign is the result of com-

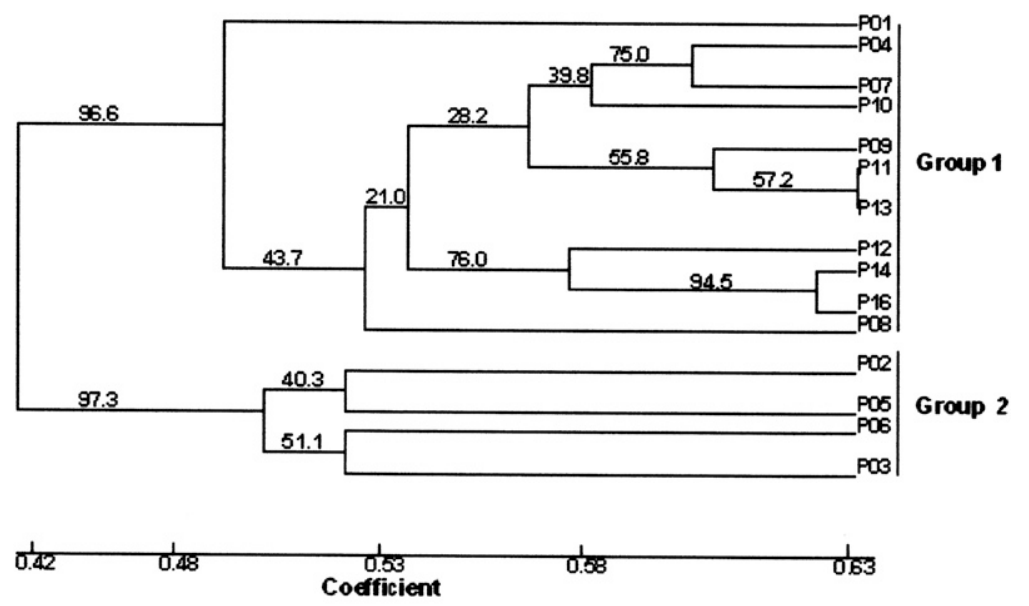

Fig. 3. The unweighted pair group method with the arithmetic mean (UPGMA) dendrogram of 15 red fescue accessions from 807 amplified fragment length polymorphism markers. The numbers at the nodes indicate the confidence limit ( $P$ bootstrap values) for the grouping (two groups marked as Group 1 and Group 2) of those accessions, which are to the right of the nodes.

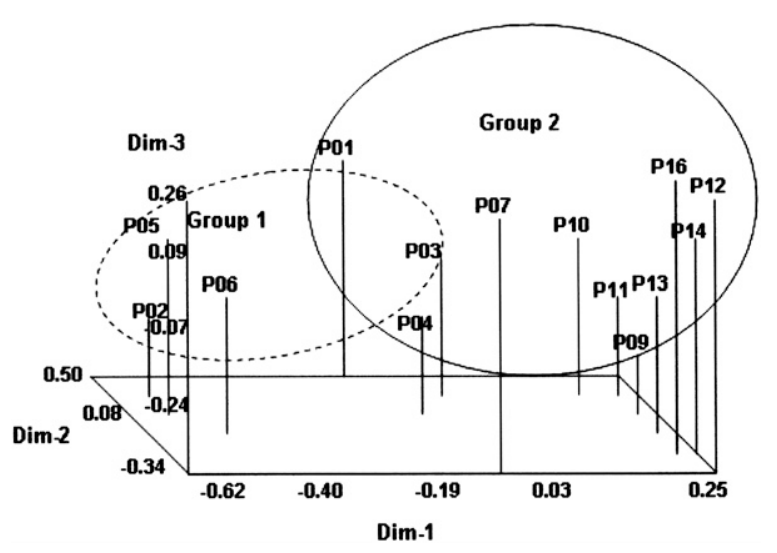

Fig. 4. Three-dimensional plot of principal coordinate analysis with 807 amplified fragment length polymorphism markers (observations) and 15 red fescue accessions defining two groups marked as Group 1 and Group 2 from the DCENTER and EIGEN options of NTSYS Version 2.1.

paring (Euclidean) distance and (Jaccard) similarity values. Comparison between the geographical matrix (Euclidean dissimilarity coefficients) obtained from Oliveira et al. (2008) and the AFLP data also showed a looser correspondence. The Mantel Z statistic indicated a nonsignificant correlation $(r$ $=0.01, P=0.5066)$ between both matrices.

Flow cytometry. Differences in DNA content among accession populations were analyzed (Table 4). Accessions of F. rubra were significantly different $(P<0.01)$. The average 2C DNA content among accessions was $11.04 \mathrm{pg}$ and ranged from 10.12 to 11.99 . The average SD of 2C DNA content among accessions was only $0.64 \mathrm{pg}$ and ranged from 0.05 to $1.23 \mathrm{pg}$.

Characterization of dollar spot susceptibility. The accession effect was significant for this characteristic (Table 5). The 15 red fescue accessions did not all display the same level of resistance to dollar spot disease. Some accessions (P13, P16, and P06) exhibited moderate resistance to dollar spot disease (mean value 5.6 or greater). The commercial cultivar Wilma was found to be susceptible to the disease (mean value $=3.9)$ (Table 6). Polymerase chain reaction was performed to control whether the symptoms found in F. rubra plants were caused by $S$. homoeocarpa. We obtained a single 500-bp band in symptomatic $F$. rubra plants, which corresponds to the amplicon size obtained from the initial sample of $S$. homoeocarpa obtained in the golf course. Furthermore, the sample of asymptomatic $F$. rubra plants did not amplify. Moreover, the amplified regions were sequenced, obtaining the same nucleotidic sequence in the initial sample obtained

Table 4. Means for 2C plant nuclear DNA content for 15 red fescue accessions ( $F$. heteromalla: P01, P02, P05, P06, P07, P09, P11; F. trichophylla ssp. asperifolia: P03, P04; F. nigrescens ssp. microphylla: P08 and P10; and F. rubra ssp. pruinosa: $\mathrm{P} 12, \mathrm{P} 13, \mathrm{P} 14$ and P16).

\section{P0}

$\mathrm{P} 01$
$\mathrm{P} 02$

\section{$\mathrm{P} 03$}

P04

P05

P06

P07
P08

P08

P09

P10

P11

P12

P13

P14

P16

Wilma

Average

F test

Least significant difference at the $5 \%$ level $(P=0.05)$

$* * P<0.01$. The least significant difference values at the bottom of each column represent the minimum difference between any two accessions necessary to be $95 \%$ confident that the difference is not attributable to chance. 
Table 5. Mean squares of the analyses of variance of dollar spot susceptibility (DSS) in 15 accessions and one control ('Wilma') of F. rubra.

\begin{tabular}{lcccr}
\hline & \multicolumn{4}{c}{ Mean squares } \\
\cline { 2 - 5 } Degrees of freedom & Replicate & Accession & Replicate $\times$ accession & Error \\
\hline DSS & 1 & 15 & 15 & 376 \\
$* * * P<0.001, \mathrm{NS}=P>0.05$ (nonsignificant). & & $2.34 \mathrm{NS}$ & 2.44 \\
\hline
\end{tabular}

Table 6. Means for dollar spot susceptibility (DSS) and DSS ratings (SD in parentheses) for 15 red fescue accessions ( $F$. heteromalla: P01, P02, P05, P06, P07, P09, P11; F. trichophylla ssp. asperifolia: $\mathrm{P} 03, \mathrm{P} 04 ; F$. nigrescens ssp. microphylla: $\mathrm{P} 08$ and $\mathrm{P} 10$; and F. rubra ssp. pruinosa: P12, P13, P14 and P16).

\begin{tabular}{lr}
\hline Accessions & DSS \\
\hline P01 & $3.6(1.5)$ \\
P02 & $2.1(1.1)$ \\
P03 & $1.0(0.0)$ \\
P04 & $4.3(1.3)$ \\
P05 & $3.4(2.3)$ \\
P06 & $5.6(1.4)$ \\
P07 & $5.0(1.9)$ \\
P08 & $3.4(1.1)$ \\
P09 & $3.4(1.9)$ \\
P10 & $4.1(2.3)$ \\
P11 & $1.9(1.5)$ \\
P12 & $2.6(1.4)$ \\
P13 & $6.3(1.8)$ \\
P14 & $2.7(1.5)$ \\
P16 & $5.7(1.4)$ \\
Wilma & $3.9(1.5)$ \\
Average & $3.6(2.1)$ \\
F test & $24.9 * * *$ \\
Least significant difference & 0.9 \\
at 5\% level & \\
$(P=0.05)$ & \\
$* * * P<0.001$. & The least significant \\
values at the bottom of each column represent the \\
minimum difference between any two accessions \\
necessary to be 95\% confident that the difference is \\
not attributable to chance.
\end{tabular}

from the golf course in the diseased plants after inoculation and in the reference sample of $S$. homoeocarpa (CBS 510.89).

\section{Discussion}

All the AFLP primer combinations tested in the present study revealed workable patterns and can be used in future studies to estimate genetic variation between other fescue populations. For this set of primers, none of the fescue accessions shared an identical DNA marker profile, indicating that the collection does not contain duplications. Specific AFLP markers were found for some species. The lack of correlation between variations of the DNA and geographical data (altitude, latitude, and longitude) is consistent with the results obtained by Phan et al. (2003) and Morales-Nieto et al. (2006). The AFLP results in this study indicated that accessions even from a narrow ecological area are genetically diverse. Local environmental adaptation may have played a significant role in Festuca diversity. A high level of genetic diversity among red fescue accessions from northern Spain was observed and does not necessarily reflect similarity or difference in agronomic traits. The correlation between GSj values based on five AFLP marker combinations with Euclidean distance values derived from agronomic traits was very low, like in other studies (Maric et al., 2004; Tar' an et al., 2005). The diversity obtained in the present study may be attributed to the fact that red fescue accessions are cross-pollinated and immersed in the center of origin of this species, including levels of ploidy and reproductive types in sympatry (Perring and Walters, 1976). In this case, from the point of view of the conservation of germplasm, the crossing of accessions inside each agronomic group is not advisable because of the risk of genetic recombination (Oliveira and Charmet, 1988-1989). Indeed, the accessions studied here are not too numerous to regenerate them individually in isolation and to maintain the seed collection by bulked seed. The choice of a "core" of this collection would be dictated by the need for seed multiplication for distribution to other gene banks of further evaluation for turf performance. It can be advised to pick up some representative accessions in each agronomic cluster and regenerate them individually in isolation as the better strategy to conserve the existent variability. Such a way allows the conservation of every "phenotype" of the red fescue accessions.

The positive relationship between DNA content obtained by flow cytometry and $2 n$ chromosome number of the accessions of $F$. rubra supports similar observations from studies of other fine fescues (Huff and Palazzo, 1998) and other turfgrass species (Arumuganathan and Earle, 1991; Eaton et al., 2004).

With the controlled screening procedure described here, we identified three accessions (P13, P16, and P06) of $F$. rubra belonging to Group 1 (P13 and P16) and Group 2 (P06) with a moderate resistance to dollar spot (mean value 5.6 or greater). The accessions P13 and P16 were classified by Oliveira et al. (2008) as F. rubra ssp. pruinosa, so they belong to the same taxon of $F$. rubra and they are also genetically similar according to the AFLP data. According to the same author, the accession P06 belongs to $F$. heteromalla taxon and because it belonged to Group2, it is genetically different from accessions P13 and P16.

Growth chamber assays used in our study are different from field assays in several aspects, particularly in the nature and amount of inoculums, plant age, and environmental factors. The limitation of the growth chamber studies reduces the potential range of disease severities that can be observed among accessions. Even with these limitations, data from growth chamber assays have demonstrated significant differences among red fescue accessions in their response to the dollar spot pathogen.
Some studies (Chakraborty et al., 2006) from pathogenicity tests show a lack of racespecific interactions in this disease, so turfgrass breeders should be able to select for resistance to one or a few virulent isolates of the pathogen and to obtain resistance to a wide array of isolates. Race nonspecific resistance is much more likely to be durable across a wide array of environments in which red fescue is grown. Although some results suggest a certain degree of race specificity for host resistance to this disease (Casler et al., 2007), it is important to evaluate each disease across a wider range of environmental conditions and pathogen isolates.

On the basis of these results, the plants in accessions P13 and P16 with the highest disease indices were selected and are being intercrossed to generate a random mating population for evaluation and phenotypic recurrent selection for disease resistance and turf performance. In the same manner, the plants with the highest disease indices in accession P06 were selected and are being crossed to generate another random mating population. The objective is to develop elite clones of red fescue with good resistance to dollar spot and superior turf quality for use in breeding new varieties of red fescue.

\section{Literature Cited}

Arumuganathan, K. and E.D. Earle. 1991. Estimation of nuclear DNA content of plants by flow cytometry. Plant Mol. Biol. Rpt. 9:229-241.

Bonos, S.A., M.D. Casler, and W.A. Meyer. 2003. Inheritance of dollar spot resistance in creeping bentgrass. Crop Sci. 43:2189-2196.

Casler, M.D., G. Jung, S.S. Bughrara, A. Hamblin, C. Williamson, and T. Voigt. 2007. Development of creeping bentgrass with multiple pest resistance. USGA Green Section Record. 45: $15-19$.

Chakraborty, N., T. Chang, M.D. Casler, and G. Jung. 2006. Response of bentgrass cultivars to Sclerotinia homoeocarpa isolates representing 10 vegetative compatibility groups. Crop Sci. 46:1237-1244.

Costich, D.E., T.R. Meagher, and E.J. Yurkow. 1991. A rapid means of sex identification in Silene latifolia by use of flow cytometry. Plant Mol. Biol. Rpt. 9:359-370.

De Nova, P.J., M. De La Cruz, J.V. Monte, and C. Soler. 2006. Genetic relationships within and among Iberian fescues (Festuca L.) based on PCR-amplified markers. Genome 49:11701183.

Dolezel, J., S. Lucretti, and I. Schubert. 1994. Plant chromosome analysis and sorting by flow cytometry. Crit. Rev. Plant Sci. 13:275-309.

Eaton, T.D., J. Curley, R.C. Williamson, and G. Jung. 2004. Determination of the level of variation in polyploidy among Kentucky bluegrass cultivars by means of flow cytometry. Crop Sci. 44:2168-2174.

Huff, D.R. and A.K. Palazzo. 1998. Fine fescue species determination by laser flow cytometry. Crop Sci. 38:445-450.

Jianming, G., Z. Shougong, Q. Liwang, Z. Yong, W. Chunguo, and S. Wenquin. 2006. ISSR and AFLP identification and genetic relationships of Chinese elite accessions from the genus Populus. Ann. For. Sci. 63:499-506.

Majidi, M.M., A.F. Mirlohi, and B.E. SayedTabatabaei. 2006. AFLP analyses of genetic 
variation in Iranian fescue accessions. Pak. J. Biol. Sci. 9:1869-1876.

Mantel, N. 1967. The detection of disease clustering and a generalized regression approach. Cancer Res. 27:209-220.

Maric, S., S. Bolaric, J. Martincic, I. Pejic, and V. Kozumplik. 2004. Genetic diversity of hexaploid wheat cultivars estimated by RAPD markers, morphological traits and coefficients of parentage. Plant Breed. 123:366-369.

Mian, M.A., A. Hopkins, and J. Zwonitzer. 2002. Determination of genetic diversity in tall fescue with AFLP markers. Crop Sci. 42:944959.

Morales-Nieto, C., A. Quero-Carrillo, O. Le-Blanc, A. Hernández-Garay, J. Pérez-Pérez, and S. González-Muñoz. 2006. Caracterización de la diversidad del pasto nativo Bouteloua curtipéndula Michx. Torr., mediante marcadores AFLP. Agrociencia 40:711-720.

Oliveira, J.A. and G. Charmet. 1988-1989. Polimorfismo isoenzimático de seis poblaciones naturales de traigrás inglés de Galicia. Pastos XVIII-XIX:69-85.
Oliveira, J.A., M.I. Gutiérrez-Villarias, M.A. Fernández-Casado, L. Costal-Andrade, E. GonzálezArráez, S.S. Bughrara, and E. Afif. 2008. Agronomic, leaf anatomy, morphology, endophyte presence and ploidy characterization of accessions of Festuca group rubra collected in northern Spain. Span. J. Agr. Res. 6:586-598.

Perring, F.H. and S.M. Walters. 1976. Atlas of the British flora. Botanical Society of the British Isles, London, UK.

Phan, A.T., Y.B. Fu, and S.R. Smith, Jr. 2003. RAPD variation in selected and unselected blue grama populations. Crop Sci. 43:1852-1857.

Rohlf, F.J. 2003. NTSYS-pc. Numerical taxonomy and multivariate analysis system.Version 2.1 [computer program]. Exeter Software, Setauket, NY.

Sneath, P.H.A. and R.R. Sokal. 1973. Numerical taxonomy. Freeman, San Francisco, CA.

SPSS ${ }^{\circledR}$. 2006. SPSS ${ }^{\circledR} 15.0$ for Windows ${ }^{\text {TM }}$. SPSS Inc., Chicago, IL.

Tar'an, B., C. Zhang, T. Warkentin, A. Tullu, and A. Vandenberg. 2005. Genetic diversity among varieties and wild species accessions of pea
(Pisum sativum L.) based on molecular markers, and morphological and physiological characters. Genome 48:257-272.

Turgeon, A.J. 2005. Turfgrass management. Pearson Prentice Hall, Upper Saddle River, NJ.

Vos, P., R. Hogers, M. Bleeker, M. Reijans, T.H. Lee, M. Van Der Hornes, A. Frijters, J. Pot, J. Peleman, M. Kuiper, and M. Zabeau. 1995. AFLP: A new technique for DNA fingerprinting. Nucleic Acids Res. 23:407-414.

Walsh, B., S.S. Ikeda, and G.J. Boland. 1999. Biology and management of dollar spot (Sclerotinia homoeocarpa); an important disease of turfgrass. HortScience 34:13-21.

Yap, I.V. and R.J. Nelson. 1996. Winboot a program for performing bootstrap analysis of binary data to determine the confidence limits of UPGMA-based dendrograms, IRRI Discussion Paper Series No. 14. International Rice Research Institute, Manila, Philippines.

Zhao, H., S. Bughrara, and J.A. Oliveira. 2006. Genetic diversity in colonial bentgrass (Agrostis capillaris L.) revealed by EcoRI-MseI and PstIMseI AFLP markers. Genome 49:328-335. 